\title{
GESTÃO E LIDERANÇA NA ENGENHARIA DE PRODUÇÃO: O MELHOR MEIO DE APLICAÇÃO EM CAMPO ATRAVÉS DE UM ESTUDO QUALI-QUANTITATIVO
}

\author{
Congresso Nacional Online de Empreendedorismo, 3a edição, de 06/12/2021 a 08/12/2021 \\ ISBN dos Anais: 978-65-81152-30-7
}

SASSO; Carlos Guilherme ${ }^{1}$, COUTINHO; Ítalo 2, SILVA; Luiz Cláudio Tavares ${ }^{3}$, SOUZA; Jorge dos Santos ${ }^{4}$, LIMA; Amanda Camerini ${ }^{5}$

\section{RESUMO}

Liderar trata-se do processo de conduzir ou influenciar determinado grupo de pessoas, com o intuito de contribuir para um melhor desempenho funcional do ambiente em que estão inseridos. Está relacionado também, com a humildade, pois pode gerar uma arrogância no sentido de saber tudo, mas o bom gestor sabe que não detém o conhecimento sobre tudo e que pode não estacionar diante uma situação considerada corriqueira. É fato que uma boa liderança somada a uma gestão de pessoas eficiente, é essencial a uma empresa, todavia, não se trata apenas disso, não tão somente às empresas, mas sim em um todo, para alcançar um equilíbrio e balanço universal. Aqueles que motivam e conduzem, consequentemente, obtém além do seu próprio sucesso, o respeito e a admiração dos liderados e garantem o êxito da empresa. O tema foi baseado em líderes e gestores do qual consegui acompanhar ao longo da vida laboral. Portanto, de tal maneira gerou uma espécie de inspiração e epifania sobre o assunto; além disso, foi embasado também em empresas das quais fui privilegiado em compor parte do quadro de funcionários. Como se trata de empresas que lidam com pessoas, de certo modo, a influência que elas têm na formação do carácter - aqui usado como uma característica, um modo de ser dapessoa - é algo extraordinário e importante, pois nos trará os profissionais quedesejamos ser ou não ser. Este trabalho tem por objetivo conhecer a fundo o processo da gestão e liderança, na qual uma se distingue da outra, embora semelhantes entre si, inclusive sobre suas peculiaridades. A pesquisa foi feita através de estudo de caso e de um estudo quali-quantitativo envolvendo pesquisa e análise de dados, recolhendo amostra e diagnósticos de relatos de pessoas e estudos que estão disponíveis em website, livros e afins. Além disso, foi elaborado um questionário para a análise dos dados que serviram para a elaboração dos gráficos complementares a pesquisa, através daferramenta "Google forms", para que viesse a lograr maior satisfação na busca pelo almejado. Passa-se a observar a figura do gestor/líder como um membro da equipenão como um mero ser onipotente, levando esse conceito e ampliando-o aoscolaboradores. Os resultados obtidos foram que: os gestores/líderes são em sua maioria, distantes de seus colaboradores, o que pode acarretar em perdas para a empresa. Pode-se concluir ainda, que há uma longa caminhada a ser percorrida, sobretudo na desmitificação de que gestor/líder são "semi deuses" dentro da empresa mas que são pessoas tanto como seus liderados. 
PALAVRAS-CHAVE: líder, gestor, habilidades, colaboradores 